\title{
ESTIMATION OF SEAGRASS COVERAGE BY DEPTH INVARIANT INDICES ON QUICKBIRD IMAGERY
}

\author{
Muhammad Anshar Amran \\ Department of Marine Sciences, Hasanuddin University, Indonesia
}

\begin{abstract}
Management of seagrass ecosystem requires availability of information on the actual condition of seagrass coverage. Remote sensing technology for seagrass mapping has been used to detect the presence of seagrass coverage, but so far no information on the condition of seagrass could be obtained. Therefore, a research is required using remote sensing imagery to obtain information on the condition of seagrass coverage.

The aim of this research is to formulate mathematical relationship between seagrass coverage and depth invariant indices on Quickbird imagery. Transformation was done on multispectral bands which could detect sea floor objects that are in the region of blue, green and red bands.

The study areas covered are the seas around Barranglompo Island and Barrangcaddi Island, westward of Makassar city, Indonesia. Various seagrass coverages were detected within the region under study.

Mathematical relationship between seagrass coverage and depth invariant indices was obtained by multiple linear regression method. Percentage of seagrass coverage (C) was obtained by transformation of depth invariant indices (Xij) on Quickbird imagery, with transformation equation as follows:

$$
\mathrm{C}=19.93463 .347 \mathrm{X}_{12}+23.239 \mathrm{X}_{23} \text {. }
$$
\end{abstract}

A good accuracy of $75 \%$ for the seagrass coverage was obtained by transformation of depth invariant indices (Xij) on Quickbird imagery.

Keywords: seagrass coverage, depth invariant index

\section{INTRODUCTION}

Seagrasses are angiosperms (flowering plants) which have fully adapted to live under the sea surface in tropic and sub-tropic regions. Seagrasses generally cover a wide area such as seagrass meadow on the sea floor exposed by sunlight. Seagrass could thrive on mud, sand and dead coral substrate.

Coresponding author: anshar_btg@yahoo.co.id 
Management of seagrass as part of coastal ecosystem requires information on the condition of seagrass. Seagrass is commonly distinguished by species diversity, vegetation density and coverage. Actual information on seagrass condition in various regions in Indonesia is still limited. The use of remote sensing satellite image is one of the options which could be used to map the seagrass.

Remote sensing technology for seagrass mapping has been used to detect the presence of seagrass coverage but so far no information on the condition of seagrass could be obtained. Therefore, a research is required using remote sensing imagery to obtain information on the condition of seagrass coverage.

The main constraint in the application of remote sensing technology for mapping of sea floor objects, including seagrass, is water column that absorbs and scatters electromagnetic energy causing attenuation of light penetration into waters. Therefore, the presence of sea floor objects that can be detected by the image is very limited by depth of penetrable water. Depth of penetration of electromagnetic wave into water column is based on wavelength of dissolved and suspended materials in water. Jupp (1988) indicated that working bands for visible light spectrum can detect objects below water level of up to 25 meters deep in the blue band region.

Another constraint is the mixing of sea floor object reflectance with water column reflectance so that the recorded radiance by sensor is not directly describing the sea floor object. Recorded radiance is influenced by optical properties and depth of water. Influence from a variation of depths can be corrected by using depth invariant index (Lyzenga 1981).

Management of seagrass ecosystem requires availability of information on the actual condition of seagrass. Remote sensing technology, especially application of Quickbird imagery is expected to get information on seagrass coverage. To obtain quantitative values of seagrass coverage from a remote sensing image, a transformation describing mathematical relationship between digital values of image with seagrass coverage is essential.

The aim of this research is to formulate mathematical relationship between the percentage of seagrass coverage and depth invariant indices on Quickbird imagery, to be applied for seagrass coverage mapping.

\section{MATERIALS AND METHODS}

The study areas covered the seas around Barranglompo Island and Barrangcaddi Island, westward of Makassar City, Indonesia. Various seagrass coverages were detected.

Satellite imagery used in this research is Quickbird, acquired on 10 April 2008, with cloud cover of approximately $2 \%$. The imagery is multi-spectral image having 4 bands consisted of band-1 (blue), band-2 (green), band-3 (red) and band-4 (near infra-red) in GeoTIFF format with spatial resolution of $2.4 \mathrm{~m}$ at gray scale level of 11 bits radiometric resolution. Research activities conducted are illustrated in the flow chart of Figure 1. 


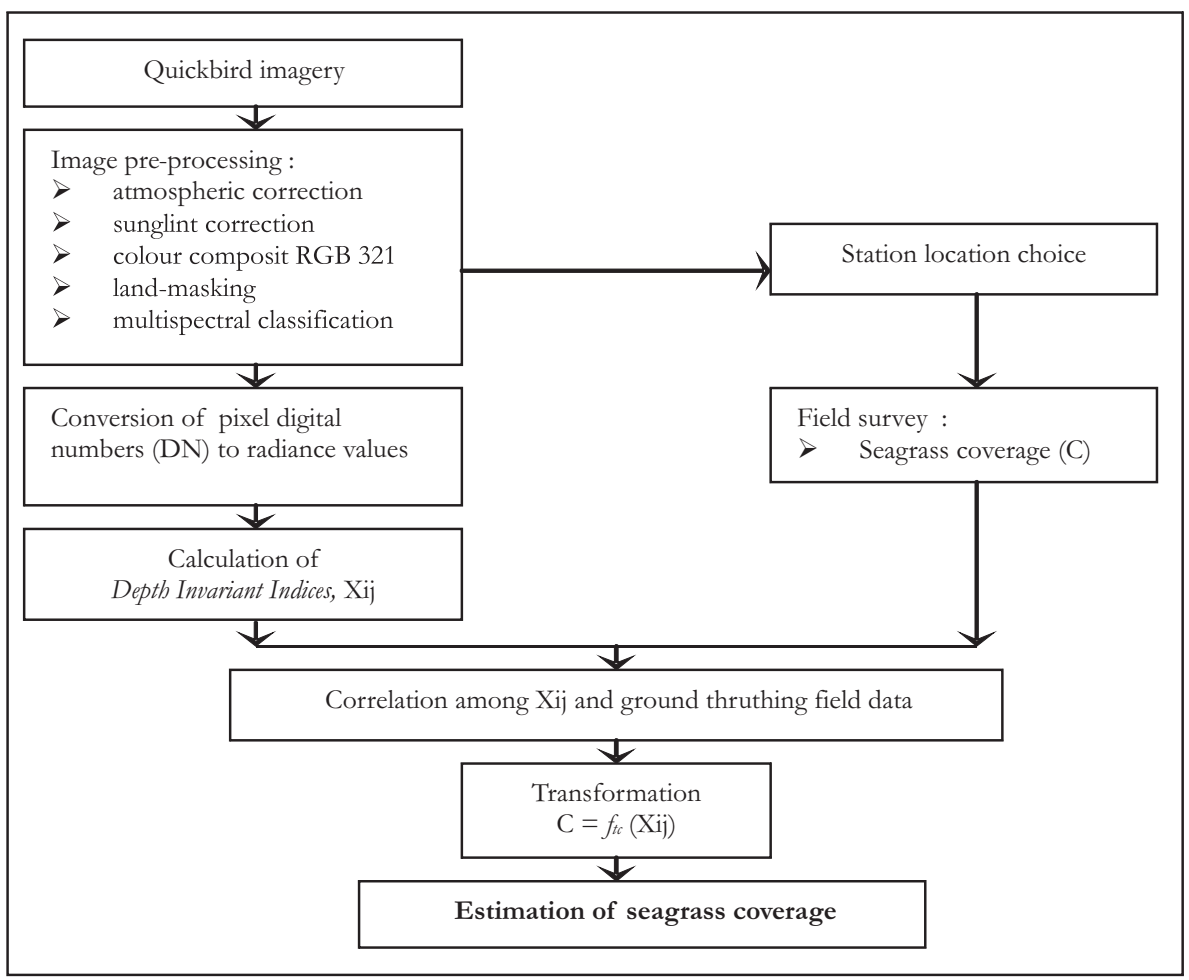

\section{Image pre-processing}

Image pre-processing covered the atmospheric correction, sunglint correction, compilation of composite image RGB321, land-masking and multi-spectral classification. Maximum likelihood method was used to classify the image. Result of classification could be applied as reference for choosing location of stations for field ground thru thing and measurement.

\section{Station location}

Ground thruthing stations were placed at regions showing the presence of various seagrass coverages condition based on the result of image classification. In every station a transecting line from beginning of presence of seagrass to a reef-slope point was set perpendicular to the coastline. Point of measurement in transect line was in the form of square plot-transect of $1 \mathrm{~m}$ x $1 \mathrm{~m}$. Distance between plot-transects was $10 \mathrm{~m}$. The percentage of seagrass coverage collected from Barranglompo Island were used in compiling transformation model, while data collected from stations at Barrangcaddi Island were applied to accuracy assessment.

\section{Field survey}

Ground thruthings were conducted to obtain parameters related to seagrass condition, i.e. identification of seagrass species and seagrass coverage. The seagrass 
species in plot-transect was identified through recognition of their different leaf forms, rhizomes, flowers and fruits. Seagrass species identification was based on the reference of McKenzie et al. (2003). Seagrass coverage was determined using the modification and combination methods of McKenzie et al. (2003) and English et al. (1994). Seagrass coverage is the proportion of substrate area covered by seagrass vegetations in a unit area if it is observed perpendicular from the top.

Seagrass coverage $(C)$ is :

$$
C=\frac{a}{A} \times 100 \%
$$

where:

$a:$ area covered by seagrass in plot-transect.

$A:$ plot-transect area

\section{Conversion of pixel digital numbers (DN) to radiance values}

Conversion of digital numbers (DN) to radiance values, for each pixel at band-i, was done by using the following formula (Krause 2003):

$$
L_{\text {band }-i}=\frac{\text { AbsCalFactor }_{\text {band }-i} \cdot D N}{\Delta \lambda_{\text {band }-i}} \mathrm{Wm}^{-2} \mathrm{sr}^{-1} \mu \mathrm{m}^{-1}
$$

where:

$$
\begin{array}{ll}
L_{\text {band-i }} & \text { : pixel radiance value for band-i } \\
\text { absCalFactor }_{\text {band }-i} & : \text { radiometric calibration factor, }\left(\mathrm{Wm}^{-2} \mathrm{sr}^{-1}\right) \\
\Delta \lambda_{\text {band }-i} & : \text { effective bandwidth }(\mu \mathrm{m})
\end{array}
$$

\section{Calculation of Depth Invariant Index}

Depth invariant indices (Xij) were calculated by using the following formula (Lyzenga 1981):

Depth invariant index, $\mathrm{Xij}=\ln (L i-L s i)-\left[\frac{k i}{k j}\right] \ln (L j-L s j)$

Where:

Li : pixel radiance on band-i

Lsi : mean pixel radiance for deep sea, on band-i

Lj : : pixel radiance on band-j

Lsj : : mean pixel radiance for deep sea, on band-j

$\left[\begin{array}{l}k i \\ k, j\end{array}\right] \quad$ ratio of attenuation coefficient between band-i and band-j

Attenuation coefficients of water column, $k i$ and $k j$, were obtained from regression equation between logarithm of image radiances to depths, that is a half of curve slope (Green et al., 2000). Transformation was done on working bands for visible light spectrum considering that electromagnetic wave in those bands can penetrate the water body. 


\section{Correlation between $\mathrm{Xij}$ and field data}

Correlation test between $\mathrm{Xij}$ with seagrass coverage data is used to determine the close linear relationship between percentage of seagrass coverage $(C)$ and Xij. Correlation test was done by calculating Pearson's moment-product correlation coefficient between $\mathrm{C}$ and $\mathrm{Xij}$.

\section{Transformation of depth invariant index}

Transformation was done by multiple linear regression between seagrass coverage (C) and Xij. Transformation equations obtained were applied to Xij image to produce a new image depicting the coverage image.

\section{Determination of seagrass condition}

Condition of seagrass meadow was determined based on the criterion of percentage of seagrass coverage as shown in Table 1 . This criterion was used to classify the condition of seagrass meadow for the coverage image.

Table 1. Seagrass condition criterion based on coverage

\begin{tabular}{|c|c|c|}
\hline Scale & Coverage & Asssigned Condition \\
\hline 5 & $>75.4 \%$ & Very good \\
\hline 4 & $50.5-75.4 \%$ & Good \\
\hline 3 & $25.5-50.4 \%$ & Rather good \\
\hline 2 & $5.5-25.4 \%$ & Bad \\
\hline 1 & $<5.5 \%$ & Very bad \\
\hline
\end{tabular}

(modified from Braun-Blanquet scale, Heijs and Brouns 1986)

\section{Accuracy assessment}

Error matrix was used to determine the accuracy assessment. Error matrix could test conformity between ground thruthing data and the result of classification (Jensen 2005). Ground thruthing data of Barrangcaddi Island was made as reference.

\section{RESULTS AND DISCUSSIONS}

\section{Image pre-processing}

Colour composite image, RGB321 (Figure 2) of Quickbird imagery was produced in this research. This composite image presented objects in their natural colour. Composite image RGB321 showed the presence of cloud covers and cloud shadows at the image. Cloud-cover at the image was found around Barrangcaddi Island, at deep sea location, but they did not cover the area where seagrasses are present. However, there was cloud shadows covered the shallow water area grown by seagrasses. To overcome this constraint, ground thruthing stations at Barrangcaddi Island were placed outside the locations of cloud-shadows. 


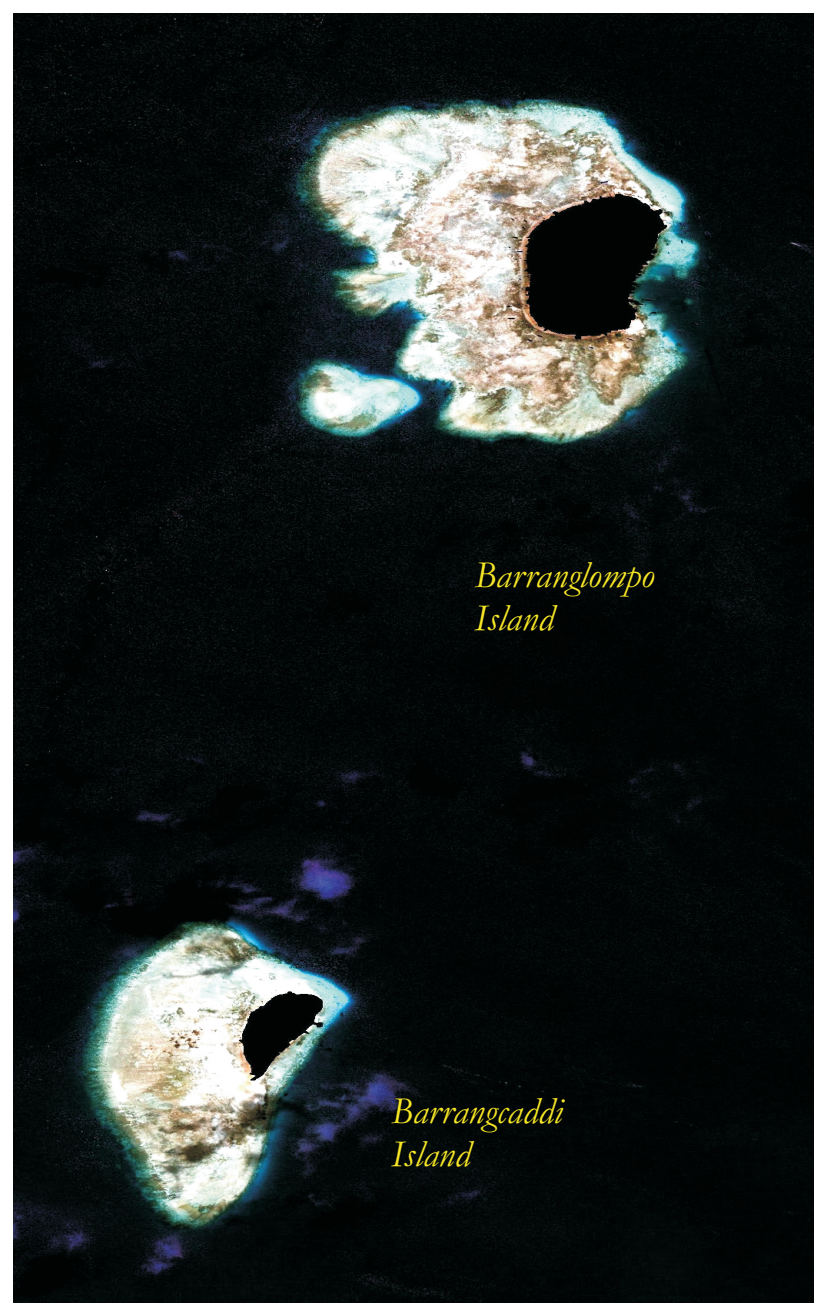

Multispectral classification was done by using maximum likelihood method at band-1, band-2 and band-3 of the image. Results of classification indicated that seagrass meadow in the open waters of Barranglompo Island and Barrangcaddi Island were widely spread in the northern, western and southern part. In general, seagrass meadows at ground thruthing are located generally adjacent to coral reefs.

\section{Percentage of seagrass coverage}

Seagrass vegetation within the study site formed a seagrass meadow spreading out alongside the open waters. Seagrass species found in this region comprised Enhalus acoroides, Cymodocea rotundata, Halodule uninervis, Thalassia hemprichii, Syringodium isoetifolium and Halophila ovalis. The dominant species with highest coverage is Enhalus acoroides. 
Percentage of seagrass coverage recorded in surrounding waters of Barranglompo Island ranged from 11.5 to $100 \%$ (damage to very good). Percentage of seagrass coverage recorded in surrounding waters of Barrangcaddi Island was around 0 93.8\% (very damage to very good).

\section{Attenuation coefficient of water column}

Early stage of $\mathrm{Xij}$ compilation was focused on calculating of attenuation coefficient of water column. Attenuation coefficients, ki, were obtained from regression equation between logarithm of image radiance and depth. Radiance values for regression analysis were selected from part of the image with sand coverage. Attenuation coefficients for band-1, band- 2 and band- 3 are: $k_{1}=0.0165 ; k_{2}=0.0220$; and $\mathrm{k}_{3}=0.0615$, respectively.

\section{Correlation between $\mathrm{Xij}$ and percentage of seagrass coverage}

Compilation of depth invariant indices (Xij) was done by using formula (3). Xij value at each field sample can be identified at Xij-image based on co-ordinate of each test plot. The values were used in Pearson's moment-product correlation test between image data and data of the percentage of seagrass coverage that has good linear relationship between percentage of seagrass coverage $(\mathrm{C})$ and Xij. Coefficient of correlation between $\mathrm{C}$ and $\mathrm{Xij}$ is presented in Table 2. Correlation test indicated that percentage of seagrass coverage $(C)$ is significantly correlated with $\mathrm{X}_{12}, \mathrm{X}_{13}, \mathrm{X}_{21}, \mathrm{X}_{23}, \mathrm{X}_{31}$ and $\mathrm{X}_{32}$. Correlation is significant at 0.01 levels (2-tailed).

Table 2. Coefficient of correlation between $\mathrm{C}$ and $\mathrm{Xij}$

\begin{tabular}{|c|c|c|c|c|c|c|}
\hline & $\mathrm{X}_{12}$ & $\mathrm{X}_{13}$ & $\mathrm{X}_{21}$ & $\mathrm{X}_{23}$ & $\mathrm{X}_{31}$ & $\mathrm{X}_{32}$ \\
\hline $\mathrm{C}$ & -0.621 & -0.576 & 0.621 & -0.491 & 0.576 & 0.491 \\
\hline
\end{tabular}

\section{Depth invariant index transformation to estimate seagrass coverage}

Image transformation is a technique to manipulate imageries that can express and present certain phenomenon on imageries. Image transformation is a mathematical transformation involving several bands to produce a new more representative image in presenting aspects related to a certain objects. Image transformation compiled in this research was the mathematical formulation relating the percentage of seagrass coverage $(\mathrm{C})$ with $\mathrm{Xij}$, in the form of multiple linear regression equation. Regression method yields 3 transformation models as follows :
$\mathrm{C} 1=19.93967 .798 \mathrm{X}_{12} 3.342 \mathrm{X}_{21} 8.321 \mathrm{X}_{32}$
with $\mathrm{R}^{2}=0.414$
$\mathrm{C} 2=63.62040 .388 \mathrm{X}_{12}$
with $\mathrm{R}^{2}=$
0.386
$\mathrm{C} 3=19.93463 .347 \mathrm{X}_{12}+23.239 \mathrm{X}_{23}$
with
$\mathrm{R}^{2}=0.414$ 


\section{Accuracy assessment}

Accuracy assessment was determined by using transformation models of $\mathrm{Xij}$ to data from Barrangcaddi Island, which was classified according to seagrass condition criterion. Accuracy assessment result of each transformation model is as follows:

model C1 is considered good enough, up to $70 \%$ accuracy. There was a big error in estimating Class 4 (good condition).

model C2 is considered not good, upto $45 \%$ accuracy. Model C2 failed to estimate Class 1 (very bad condition) and Class 2 (bad condition).

$\square$ model C3 is considered good enough, up to $75 \%$ accuracy. Accuracy of each class exceeds $50 \%$.

\section{Application of transformation model Xij}

Model C3 was selected as the best model for the estimation of seagrass coverage, based on accuracy assessment results of transformation models. The selected transformation model was applied in Xij image, producing "map of seagrass condition based on percentage of seagrass coverage" (Figures 3 and 4).

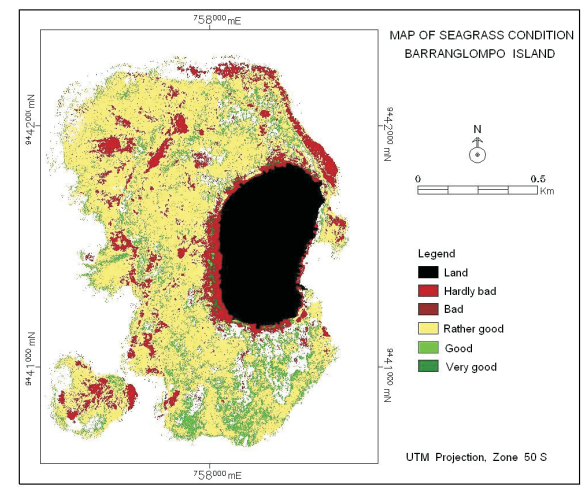

Figure 3. Map of seagrass condition of Barranglompo Island

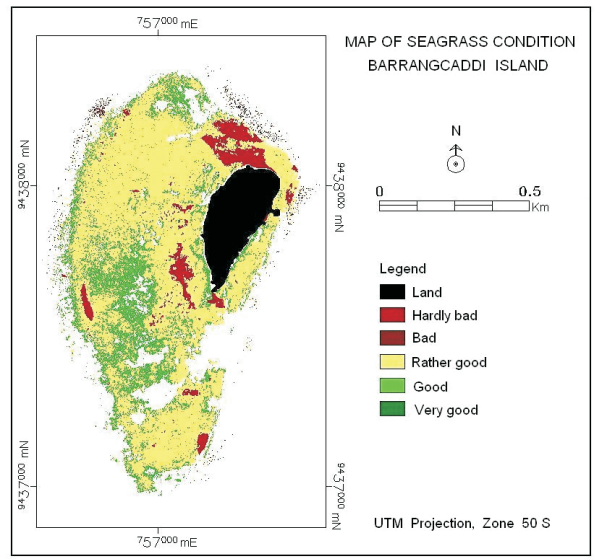

Figure 4. Map of seagrass condition of Barrangcaddi Island 
The map of seagrass condition of Barranglompo Island and Barrangcaddi Island showed that most of seagrass meadows in the region were in the category of bad and rather good condition. Percentage of seagrass coverage in the region was generally less than $50 \%$. Intense of public activities in the surrounding water could increase the damage of seagrass condition. Therefore, there is a need to conserve and rehabilitate seagrass ecosystem in this region. One effort proposed could be in the area of seagrass transplantation to prevent further degradation of the existing seagrass condition.

\section{CONCLUSIONS}

Seagrass coverage $(\mathrm{C})$ was obtained by transformation of depth invariant indices (Xij) on Quickbird imagery. The transformation equation was $C=19.93463 .347 \mathrm{X}_{12}+$ $23.239 \mathrm{X}_{23}$. An accuracy of up to $75 \%$ of the seagrass coverage estimation was obtained by transformation of depth invariant indices (Xij) on Quickbird imagery. Percentages of seagrass coverage in the surrounding water of Barranglompo Island and Barrangcaddi Island was generally less than $50 \%$.

\section{REFERENCES}

English, S., Wilkinson, C. and V. Baker. 1994. Survey Manual for Tropical Marine Resources. Australian Institute of Marine Science, Townsville, p. 235264.

Green, E.P., Mumby, P.J., Edwards, A.J. and C.D. Clark. (Ed. A.J. Edwards), 2000. Remote Sensing Handbook for Tropical Coastal Management. Coastal Management Sourcebooks 3, UNESCO, Paris. x + 316 pp.

Heijs, F.M.L. and J.J.W.M. Brouns. 1986. A Survey of Seagrass Communities around The Bismarck Sea, Papua New Guinea. Proceedings of the Koninklijke Nederlandse Akademie van Wetenschappen, C89.

Jensen, J.R., 2005, Introductory Digital Image Processing : A Remote Sensing Perspective, $3^{\text {rd }}$ ed., Pearson Prentice Hall, London, xvi $+526 \mathrm{pp}$.

Jupp, D.L.B., 1988, Background and Extensions to Depth of Penetration (DOP) Mapping in Shallow Coastal Water. Proceedings of the Symposium on Remote Sensing of the Coastal Zone, Gold Coast, Queensland, September 1988, IV.2.1 IV.2.19.

Krause, K., 2003. Radiance Conversion of Quickbird Data, Digital Globe, Colorado. 18 p.

Lyzenga, D.R., 1981, Remote Sensing of Bottom Reflectance and Water Attenuation Parameter in Shallow Water using Aircraft and Landsat Data. International Journal of Remote Sensing, 2, 7182.

McKenzie, L.J., Campbell, S.J. and C.A. Roden. 2003. Seagrass-Watch : Manual for Mapping and Monitoring Seagrass Resources by Community (citizen) Volunteers, $2^{\text {nd }}$ edition, Northern Fisheries Cetre, Cairns, $100 \mathrm{p}$. 